\title{
ヒト腸内細菌の産生する蓚酸分解酵素の部分精製
}

\author{
帝京大学医学部附属市原病院泌尿器科
}

伊藤 晴 夫

\section{PARTIAL PURIFICATION OF OXALATE DEGRADING ENZYME PRODUCED BY HUMAN INTESTINAL BACTERIA}

\author{
Haruo Ito \\ Department of Urology, Teikyo University School of Medicine, Ichihara Hospital
}

It is unclear whether the oxalate in foods degrades or not in the intestinal tract. We isolated oxalic acid decarboxylase from anaerobic bacteria present in human feces which was grown in the culture medium containing oxalic acid as the sole carbon source. The enzyme was partially purified by $80 \%$ ammonium chloride precipitation, DEAE-cellulose chromatography and molecular sieve chromatography. The amino acid composition was found to be relatively rich in glycine and alanine, but to have low basic, hydrophobic and aromatic amino acid residues compared with average proteins.

Key words: urolithiasis, intestinal bacteria, oxalate decarboxylase

\begin{abstract}
要旨：食物に含まれる蓚酸が腸管内で分解されるかどうかは不明である。そこで，ヒト䔬便より蓚酸分 解菌を分離し，この菌体より蓚酸分解酵素を分離・精製することを試みた，成年男子䔬便を炭素源が葆 酸である液体培地で嫌気性条件下に長期継代することにより蓚酸分解菌を選択することができた。この 菌の産生する oxalate decarboxylase を硫安分画, DEAE セルロースクロマトグラフィー, 分子篩クロ マトグラフィーなどで分離・精製した。この酵素のアミノ酸組成の特徵はグリシンとアラニンを比較的 多く含夕, 塩基性アミノ酸, 蹯水性アミノ酸および芳香族アミノ酸が少ないことであった. キーワード：尿路結石, 腸内細菌, 苳酸脱炭酸酵素
\end{abstract}

\section{緒言}

腸性高蓚酸尿症では腸管よりの蓚酸の吸収がえ進し ているが，その原因の一部は腸内の蓚酸分解菌の増殖 が抑制されているためとされる122)。また，特発性の腎 結石患者でも，蓚酸の腸管よりの吸収がその程度は軽 いが，六進していると言われる ${ }^{344}$. 尿中苳酸の軽度の 上昇は尿中蓚酸カルシウムの過飽和状態に対して著明 な影響を与えるので5)6)，腸管よりの蓚酸の吸収が軽度 でも上昇することは重要な意味をもつ可能性がある。 最近，ヒト腸内に蓚酸を分解する菌が存在することが 報告された7).このことが, 腸内に打ける苳酸の分解・ 吸収ひいては莜酸の尿中排泄量にどの程度の影響を与 えているかは不明である。そこで，まず，七ト䔬便よ り得られた苳酸分解菌より苳酸分解酵素を抽出分離す ることを試みた。

材料と方法

蓚酸分解菌の分離
Barber 液体培地 ${ }^{8}$ に成人男子䔬便を約 $5 \sim 10 \%$ 加 え, $37^{\circ} \mathrm{C}$, 嫌気下に培養した。この培地の炭素源は蓚 酸であり，長期継代することにより蓚酸分解菌を選択 した. 継代は培養物を新培地に $5 \sim 10 \%$ 添加して行っ た。

蓚酸の検出

培養上清中の蓚酸は高速液体クロマオグラフィー （HPLC）で測定した．使用条件は下記のごとくであっ た.

カラム: Shodex Ionpak KC811 $(30 \mathrm{~cm})$

カラム温度 : $40^{\circ} \mathrm{C}$

移動相：0.1\%phosphoric acid

流速 : $1.0 \mathrm{ml} / \mathrm{min}$

検出：220nm の紫外部吸収

クロマトグラフィー

$\mathrm{DEAE}$ セルースクロマトグラフィーは $2 \times 15 \mathrm{~cm}$ のカラムを使用した。 $0.05 \mathrm{M}$ リン酸緩衝液, $\mathrm{pH} 7.0$ 中 
の $\mathrm{NaCl} 0$ 0.3M まで linear gradientにして溶出 した. 1 フラクションは2ml である. $\mathrm{CM}$ セルロースク ロマトグラフィーも DEAEセルロースクロマトグラ フィーと同じ条件で行った。

分子節クロマトグラフィーは Sephacryl S-200を使 用した。 カラムは $2 \times 110 \mathrm{~cm}$ で, 溶出液は $0.05 \mathrm{M}$ リン酸 緩衝液, $\mathrm{pH} 7.0$ である.蛋白の溶出は $230 \mathrm{~nm}$ の吸収に よりモニターした。

分光測光法

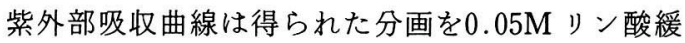
衝液, pH 7.0に溶解し Beckman DU-40 Spectrophotometer で220nm〜320nm まで測定した。

円二色性はJASCO-60 Circular dichroic spectrometerにより測定した。得られた分画を $0.05 \mathrm{M}$ リン酸緩衝液， pH 7.0に溶解した。 1mm light path thickness $の$ cylindrical cuvette far UV region (200 250nm) そ, $10 \mathrm{~mm}$ light path thickness cylindrical cuvette $を$ near UV region（250 300nm）測定に 使用した。

\section{蛋白定量}

蛋白定量は Lowry 法9)変法で行い, phenolic reagentを使用した。 $10 \mu \mathrm{g}$ から $50 \mu \mathrm{g}$ の牛血清アルブミ ンを標準として用いた。

\section{酵素活性の測定}

蓚酸脱炭酸酵素活性は下記の反応により NAD が還 元されて生ずる $\mathrm{NADH}$ の340nm における吸収を測定 することにより行った。

Oxalate $\stackrel{\text { oxalate decarboxylase }}{\longrightarrow}$ Formate + $\mathrm{CO}_{2}$

Formate $+\mathrm{NAD}^{+} \stackrel{\text { formate }}{\mathrm{DH}} \longrightarrow \mathrm{CO}_{2}+\mathrm{NADH}+$ $\mathrm{H}^{+}$

アッセイ系は次の内容を含む。

MOPS (3-[N-morpholino]propanesulfonic acid), $0.1 \mathrm{mM}, \mathrm{pH} 7.0$ $2.5 \mathrm{ml}$

NAD $10 \mu \mathrm{M}$ $0.1 \mathrm{ml}$ sodium oxalate $10 \mu \mathrm{M}$ $0.1 \mathrm{ml}$ formate dehydrogenase (Boehringer Mannheim) 8 units $0.05 \mathrm{ml}$ sample solution $0.05 \mathrm{ml}$ 0 分および $37^{\circ} \mathrm{C}, 30$ 分インキュベート後の吸光度を Perkin・Elmer Lambda 7 分光光度計で測定した。 アミノ酸分析
試料を $6 \mathrm{~N} \mathrm{HCl}$ 中で常法通り 24,48 抢よび72時間加 水分解した. 加水分解後, 真空中で $\mathrm{HCl}$ を除去し, ク エン酸緩衝液 $(\mathrm{pH}$ 2) に溶解し Beckman amino acid analyzer (Model 119 C) で分析した。

結 果

蓚酸分解活性は嫌気条件下に抢ける培養時の及維持 可能であった，培養により選択された菌は数種類のグ ラム陰性菌の混合したものであり(図 1)，まだ単一菌 を得るにはいたっていない。代表的な菌（桿菌）の電 顕写真を図 2 に示した。継代培養ブロスから集菌，洗 浄した菌混合物は，同ブロス成分存在下で培養したと きのみ活性出現した。細菌培養液を $10,000 \mathrm{~g}, 20$ 分遠沈 して得られた沈渣を $0.05 \mathrm{M}$ リン酸緩衝液, $\mathrm{pH} 7.0$ に溶 解した. 50 ワットで 3 回， 1 分間ずつ sonication した 後, 冷却遠心器で $12,000 \mathrm{rpm}, 25$ 分遠沈して, 上清を得

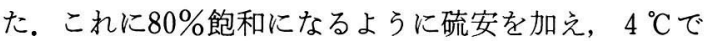

図 1 培養により選択された菌のグラム染色.グラム 陰性菌である。

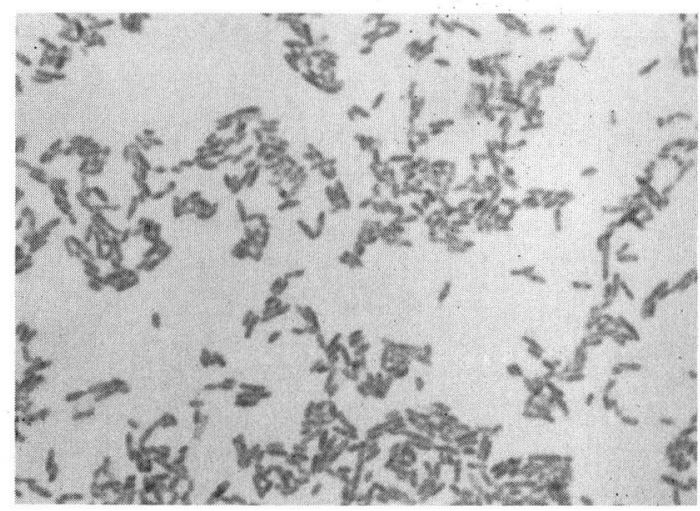

図 2 代表的な菌（桿菌）の電顕写真

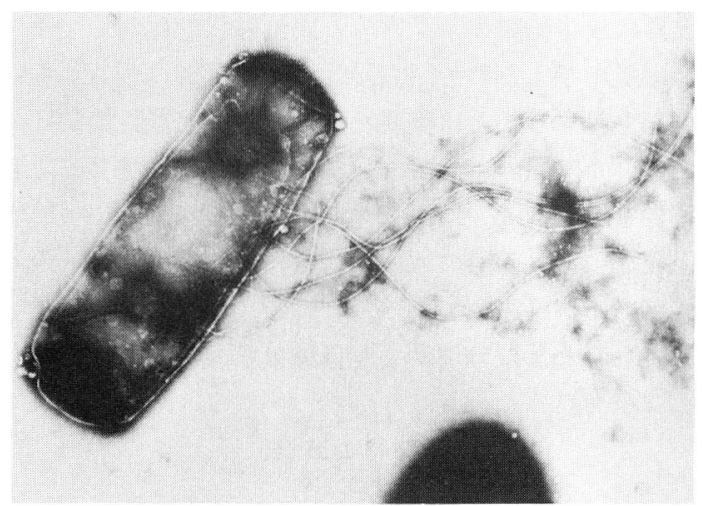


一夜，攪挥した。 $12,000 \mathrm{rpm}, 25$ 分遠沈し，沈渣を $5 \mathrm{ml}$ の0.05M リン酸緩衝液, $\mathrm{pH} 7.0$ に溶解した。この溶液 を2lの同じ緩衝液に対して透析して，硫安を除去 し, $-80^{\circ} \mathrm{C}$ に保存した。

図 3 にDEAE クロマトグラフィーの結果を示した。 酵素活性は低い $\mathrm{NaCl}$ 濃度で溶出された。この酵素が

図 3 DEAE セルロースクロマトグラフィー

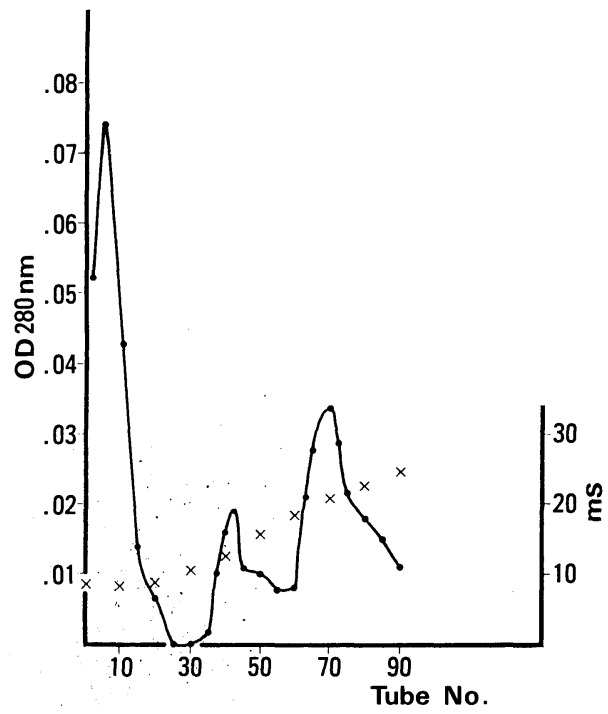

図 $4 \mathrm{CM}$ セルロースクロマトグラフィー

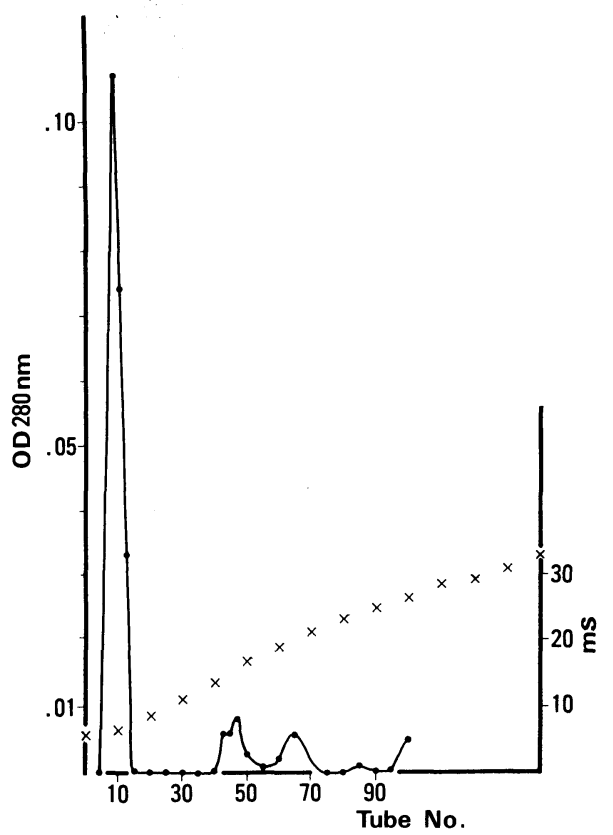

positive に荷電されている可能性が考えられたので $\mathrm{CM}$ セルロースクロマトグラフィーを行った。 ここで も酵素活性は低い $\mathrm{NaCl}$ 濃度で溶出された(図 4 ). $\mathrm{pH}$

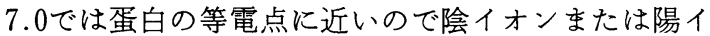
オン交換樹脂では充分に補足されないのではないかと 考学られた。

DEAE セルロースクロマトグラフィーで最初に溶 出された酵素的に活性のある分画を, 分子笠クロマト グラフィーにかけた結果を図 5 に示した。

図 5 分子篩クロマトグラフィー

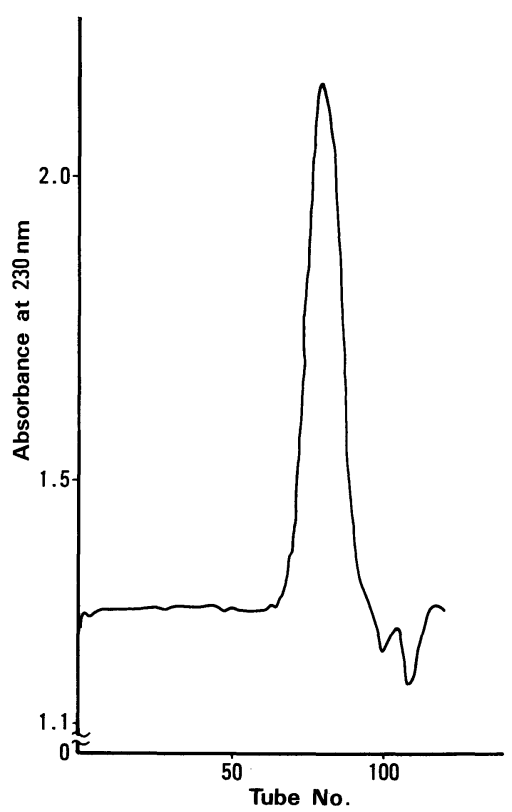

図 6 紫外部吸収スペクトラム

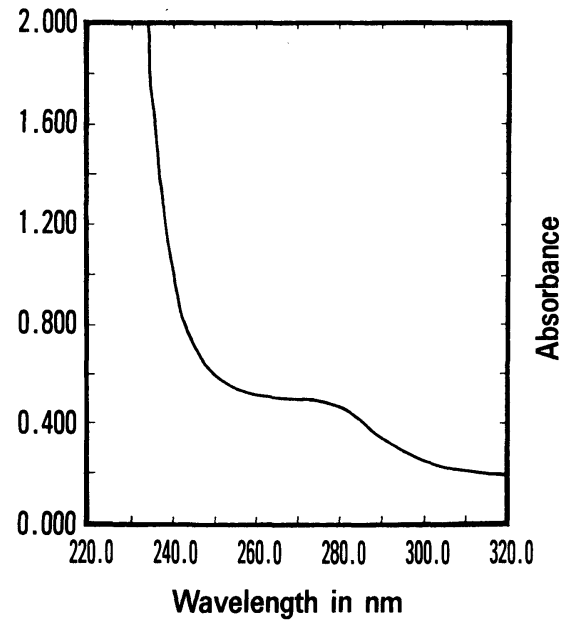


10000

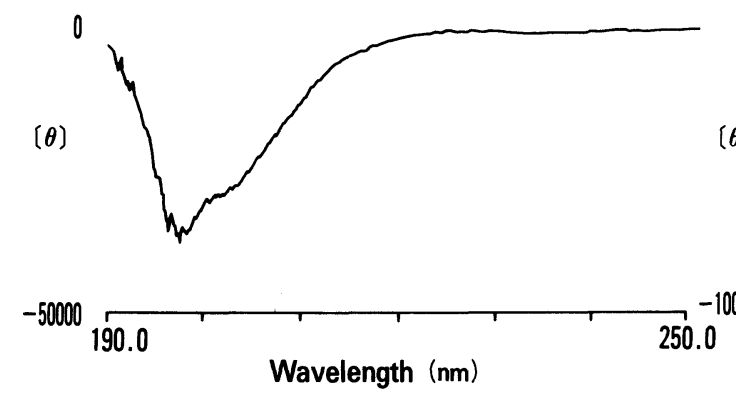

表 1 アミノ酸分析結果

\begin{tabular}{l|c}
\hline & mole \% \\
\hline Glycine & 43.47 \\
Alanine & 13.15 \\
Glutamic acid & 10.02 \\
Aspartic acid & 7.12 \\
Serine & 5.41 \\
Proline & 3.70 \\
Arginine & 3.21 \\
Valine & 2.82 \\
Lysine & 2.69 \\
Leucine & 2.39 \\
Threonine & 2.25 \\
Isoleucine & 1.34 \\
Phenylalanine & 1.12 \\
Histidine & 0.90 \\
Tyrosine & 0.41 \\
\hline
\end{tabular}

DEAEセルロースクロマトグラフィーおよび分子 篩クロマトグラフィーにより得られた分画の紫外部吸 収スペクトラムを図 6 に示した. $280 \mathrm{~nm}$ に拈ける紫外 部吸収が比較的弱いのは芳香族アミノ酸含量が少ない ことをあらわしていると思われる。

円二色性の測定では far UV region に $197 \mathrm{~nm}$ の強 い陰性のバンドが示された（図 7 ).

アミノ酸分析の結果は表 1 に示したごとくであり， グリシンとアラニンを比較的多く含み, 塩基性, 蹯水 性, および芳香族アミノ酸は少なかった。

\section{考察}

シスチン結石 ${ }^{10)}$ や尿酸結石あるいはリン酸・アンモ ニウム・マグネシウム結石の形成がその尿中に扔ける 濃度と尿の $\mathrm{pH}$ とでほぼ説明がつくのと異なり, 葆酸 カルシウム結石の形成メカニズムはより複雑である. すなわち結石の素材となるカルシウムと蓚酸が尿中で
50.0

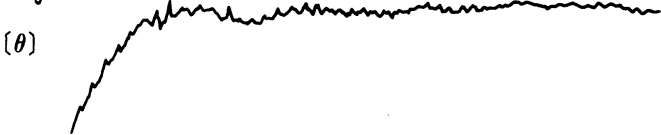

$-100.0$

250.0

Wavelength $(\mathrm{nm})$

310.0

過飽和の状態となると結晶核が形成され，これが成長 ないし凝集してゆき結石が形成される。しかし，尿中 には結晶成長・凝集に対する抑制物質が含まれてい $3^{11112)}$. これより, 結石形成は尿中の溶質濃度と抑制物 質とのかねあいで決まる。今回はこれらのらちの苳酸 の代謝に関係するかもしれない腸内細菌の産生する苳 酸分解酵素について研究した。

蓚酸を分解する菌は反留動物，草食動物，絜歯類の みならずヒトの腸管からも発見された ${ }^{13)}$. 草食動物の ように多量の蓚酸を摂取する場合には腸管中にこれを 分解する菌が常在することは蓚酸の毒性を除く重要な 意味をもつであろら。ヒトに扎いても腸性高蓚酸尿症 の発生に腸内細菌が関与する可能性が明らかにされ た ${ }^{122}$. すなわち, 胆汁酸のデオキシコール酸が葆酸分 解菌の增殖を抑制するので食慨中蓚酸が大腸で分解さ れることが少なく，そのために大量の蓚酸が吸収され てしまう。な拉，本症のさいには脂肪の吸収不良があ るため長鎖脂肪酸がカルシウムと結合し，カルシウム と結合しない吸収可能な遊離の蓚酸が増加している。 このような特殊な疾患を認めない原因不明の腎結石患 者に执いても腸内の苳酸分解菌の異常が結石形成の一 因である可能性も否定はできないであろう。

さて，ヒト䔬便が蓚酸を分解することは1940年 Barber らにより報告された ${ }^{8)}$. 彼らはこの現象は芽胞を形 成しない微生物により引き起こされると推測した。

Hayaishi らは土壤中の細菌より他の蓚酸脱炭酸酵素 を分離した ${ }^{15)}$.この酵素の至適 $\mathrm{pH}$ は6.9であり, 補酵 素としてATP, CoA, acetate, Mgイオン, thiamine pyrophosphateを必要とした。この 1 年後に, Shimazono と Hayaishi は Collybia velutipesより蓚酸脱 炭酸酵素を分離した ${ }^{14)}$.この酵素の至適 $\mathrm{pH}$ 2.5 4.0の間であり, その $\mathrm{Km}$ は $2.05 \times 10^{-3} \mathrm{M}$ であっ 
た.Quayl ら ${ }^{16)}$ は Pseudomonas oxalaticusより苳酸 脱炭酸酵素を分離した。この酵素は活性発現のために は上記と同じ補酵素を必要とした。 Allisonらはヒト の消化管内より得られた Oxalobactor formigenes よ り蓚酸脱炭酸酵素を分離した ${ }^{7)}$ 。この酵素は上記と同 じ補酵素を必要とした。また， $\mathrm{pH} 7.0$ に打ける $\mathrm{Km}$ 值 は5.7mMであった。

本実験において，われわれはヒト䔬便より分離され た菌体より蓚酸脱炭酸酵素を分離した。本酵素の至適 pHは7.0であったが， thiamine pyrophosphateを必 要としなかった。この酵素は thiamine pyrophosphate や CoA と密に結合しているため, これらを要求しな いものと推測される。しかし, 本酵素は formate dehydrogenase とカップリングするとき NADを必要とし た. 以前に報告された酵素のアミノ酸組成, 分子量, 紫外部吸收などのデータは発表されていないので，こ れらと本酵素との分子性状を比較することはできな かった。

腸内の蓚酸分解菌から苳酸分解酵素を分離精製でき れば，本酵素之腎結石形成との関係について，さらに は結石の再発予防, 結石溶解などへの応用の可能性に ついても検討できるであろう。

\section{文献}

1) Argenzio, R.A., Allison, J.A. and Allison, M.J. : Intestinal oxalate-degrading bacteria reduce oxalate absorption and toxicity in guinea pigs. J. Natr., 118, 787-792, 1988.

2）伊藤晴夫：腎結石形成に腸内細菌は関与するか. 医学のあゆみ，152，602，1990。

3) Robertson, W.G., Peacock, M., Ouimet, D., Heyburn, P.J. and Rutherford, A.: The Main Risk Factor for Calcium Oxalate Stone Disease in Man: Hypercalciuria or Mild Hyperoxaluria ? Urolithiasis, Smith, L., ed., p. 3-12, Plenum Press, New York, 1981.

4）伊藤晴夫, 真田寿彦, 村上光右, 宮内大成, 島崎 淳: 蓚酸代謝異常々尿路結石. 第 4 編. 蓚酸カルシ ウム結石患者尿中への蓚酸排泄量について。 日泌 尿会誌，69，643-646， 1978.

5) Finlayson, B.: Renal lithiasis in review. Urol.
Clin. N. Am., 1, 181-212, 1974.

6) Robertson, W.G. and Peacock, M.: The cause of idiopathic calcium stone disease. Hypercalciuria or hyperoxaluria? Nephron., 26, 105-110, 1980.

7) Allison, M.J., Cook, H.M., Milne, D.B., Gallagher, S. and Clayman, R.V.: Oxalate degradation by gastrointestinal bacteria from humans. J. Nutr., 116, 455-460, 1986.

8) Barber, H.H. and Gallimore, E.J.: The metabolism of oxalic acid in the animal body. Biochem. J., 34, 144-148, 1940.

9) Lowry, O.H., Rosebrough, N.J., Farr, A.L. and Randall, R.J.: Protein measurement with the Folin phenol reagent. J. Biol. Chem., 193, 265-275, 1951.

10) Ito, H., Murakami, M., Miyauchi, T., Yamaguchi, K., Usui, T. and Shimazaki, J.: The incidence of cystinuria in Japan. J. Urol., 129, 1012-1014, 1983.

11) Ito, H. and Coe, F.L.: Acidic peptide and polyribonucleotide crystal growth inhibitors in human urine. Am. J. Physiol., 233, F455-F463, 1977.

12）伊藤晴夫, 島崎 淳: 苳酸カルシウム結晶の成長 を抑制する高分子物質についての研究. 第 3 編. 苳 酸カルシウム結晶成長を抑制する高分子物質につ いて。 日泌尿会誌，69，1349-1354，1978.

13) Donne, L.T., Liebman, M. and Caldwell, D.R. : Microbial oxalate degradation: Effects on oxalate and calcium balance in humans. Nutr. Res., 9, 957-964, 1989.

14) Shimazono, H., Hayaishi, O.: Enzymatic decarboxylation of oxalic acid. J. Biol. Chem., 227, 151-159, 1957.

15) Jacoby, W.B., Ohmura, E. and Hayaishi. : Enzymatic decarboxylation of oxalic acid. J. Biol. Chem., 222, 435-446, 1956.

16) Quayle, J.R., Keech, D.B. and Taylor, G.A. : Carbon assimilation by Pseudomonas oxalaticus. 4. Metabolism of oxalate in cell-free extracts of the organism growth on oxalate. Biochem. J., 78, 225-236, 1961.

（1992年 6 月 1 日受理，特別掲載） 